\title{
Tvungen identitet - en vurdering av norsk forvaltningspraksis' krav om irreversibel sterilisering ved endring av juridisk kjønn
}

\author{
Anniken Sørlie
}

Anniken Sørlie er master i rettsvitenskap fra UiO siden høsten 2012. Hun begynte som stipendiat ved Institutt for offentlig rett ved Universitetet i Oslo i 2013 tilknyttet prosjektet Kjønnsidentitet og seksuell orientering i internasjonal og nasjonal rett.

I artikkelen gis det en juridisk vurdering av kravet om irreversibel sterilisering for endring av juridisk kjønn for personer som er transseksuelle, med hovedvekt på Den europeiske menneskerettighetskonvensjonen (EMK) artikkel 8. For endring av juridisk kjønn stilles det krav om kirurgisk og irreversibel fjerning av reproduktive organer, slik at opprinnelig, biologisk reproduktiv evne opphører med endelig virkning. Kravet er utviklet gjennom medisinsk praksis etablert på 1970-tallet, og har ikke hjemmel i lov. I artikkelen vurderes vilkåret opp mot EMK artikkel 8 om retten til privatliv. Artikkelen bygger på forfatterens masteravhandling fra 2012: Retten til kjønnsidentitet som menneskerettighet: Kan norsk forvaltningspraksis' krav om irreversibel sterilisering ved endring av fødselsnummer forsvares?, publisert i Kvinnerettslig skriftserie nummer 90/2013. "Transperson" fungerer som et paraplybegrep for personer som har en kjønnsidentitet eller et kjønnsuttrykk som er forskjellig fra kjønnet tillagt ved fødselen, og som omfatter blant annet transseksuelle, transvestitter og androgyne. Transpersoner opplever i varierende grad uoverensstemmelse mellom egen kjønnsidentitet og kjønnet registrert ved fødselen - såkalt juridisk kjønn.

\section{Trans og juridisk kjønn ${ }^{1}$}

Juridisk kjønn er ensbetydende med fødselsnummeret vi er registrert med i Folkeregisteret. Det fremkommer av personnummerdelen av fødselsnummeret. Fødselsnummeret består av elleve siffer. De første seks sifrene er innehaverens fødselsdato, mens de siste fem sifrene består av tre individsifre og to kontrollsifre. Det siste individsifferet er ulikt for menn og kvinner - partall for juridiske kvinner og oddetall for juridiske menn, jf. folkeregistreringsforskriften $\S 2-2^{2}$.

\footnotetext{
${ }^{1}$ Takk for kommentarer og merknader fra professor dr. juris Anne Hellum og redaksjonen i FAB.

${ }^{2}$ Forskrift 9. november 2007 nr. 1268.
} 
Etter folkeregisterloven skal personer som er bosatt i Norge, ha et fødselsnummer, jf. $\S 4 .^{3}$ Skatte- og avgiftspliktige utenlandske personer som skal oppholde seg i Norge i mindre enn seks måneder, tildeles et D-nummer. ${ }^{4}$ Slik er alle i Norge registrert som enten mann eller kvinne. Lovverket åpner ikke for individuelle forståelser av kategoriene eller for fri adgang til å endre hvilken kategori man er registrert som. ${ }^{5}$ Det gjelder til tross for de store variasjonene i hvordan vi definerer oss selv: som mann, kvinne, begge deler eller ingen av delene. Samtidig knytter vi det å være mann eller kvinne til ulike ting - mens noen forstår kjønn ut fra genitalier eller kromosomer, er kjønn for andre løsrevet fra dette.

Fødselsnummeret fremkommer blant annet på førerkort, pass, bankkort og studentkort identitetsdokumenter vi anvender i hverdagen. Slik blir en persons juridiske kjønn svært synlig i samfunnet og er en kategori hver enkelt ikke kan velge å usynliggjøre eller begrense innsynet i selv. Den utstrakte bruken av fødselsnummeret og juridisk kjønn kan føre til ubehagelige situasjoner hvor innehaveren må utlevere personlig informasjon om eget liv for at legitimasjonen skal bli godtatt.

Endring av juridisk kjønn, som muliggjør endring av alle dokumenter hvor kjønn fremgår, deriblant pass og vitnemål, gjør at man kan bli lest og respektert som det kjønnet man lever og definerer seg som. Det kan slik betraktes som samfunnets endelige aksept av en persons kjønnsidentitet. Gjennom endringen tillates man å ta del i samfunnet som det individet man er og føler seg som. Endringen kan i mange tilfeller gjøre livet verdt å leve. ${ }^{6}$

\subsection{Transseksualisme og kjønnsbekreftende behandling}

Adgangen til å endre juridisk kjønn er begrenset. Kun personer som har fullført kjønnsbekreftende behandling her eller i utlandet ${ }^{7}$, kan endre juridisk kjønn i Norge. For kjønnsbekreftende behandling i Norge kreves diagnosen transseksualisme.

Transseksualisme inngår i WHOs klassifikasjonssystem over sykdommer: ICD-10. I den norske utgaven av klassifikasjonssystemet er F64.0 transseksualisme definert slik:

\footnotetext{
${ }^{3}$ Lov 16. januar 1970 nr. 01. Erstattet lov 15. november 1946 nr. 2.

${ }^{4}$ Skatteetaten, D-nummer.

${ }^{5}$ Se mer om dette under punkt 2.2.

${ }^{6}$ Mer om dette under punkt 1.2.

${ }^{7}$ Etter fullført behandling i utlandet må Helsedirektoratet bekrefte at kjønnsbekreftende behandling er gjennomført før nytt fødselsnummer tildeles av Skattedirektoratet. En av forutsetningene for Helsedirektoratets bekreftelse er at en norsk lege har stadfestet at personens kjønnskjertler er blitt fjernet. Helsedirektoratet (2014).
} 
"Sterkt ønske om å leve og bli akseptert som tilhørende det annet kjønn. Følelse av avsky for, og ofte utilstrekkelighet ved, eget anatomisk kjønn ledsager vanligvis lidelsen. Ønske om kirurgisk eller hormonell behandling for å gjøre kroppen i mest mulig samsvar med det foretrukne kjønn, er vanlig." ${ }^{8}$

Diagnosen transseksualisme er, som nevnt, en forutsetning for kjønnsbekreftende behandling i Norge. ${ }^{9}$ Kjønnsbekreftende behandling tilbys på Seksjon for transseksualisme (tidligere GIDklinikken) ved Oslo Universitetssykehus, Rikshospitalet. Rikshospitalet har vært nasjonal behandlingsinstitusjon for transseksualisme siden 1979. Kjønnsbekreftende behandling skal lindre lidelsene man kan oppleve som følge av manglende samsvar mellom kjønnsidentiteten og kjønnet tillagt ved fødselen. Lidelsene beskrives som "klinisk stress, med permanent sosial, yrkesmessig eller familiær funksjonsnedsettelse". ${ }^{10}$

Diagnosen transseksualisme stilles etter omtrent to år med psykiatrisk utredning og såkalt virkelighetserfaring ("real-life testing"). ${ }^{11}$ Deretter følger endokrinologiske undersøkelser før hormonbehandlingen påbegynnes. Aldersgrensen er 16 år. For å begynne på pubertetsutsettende behandling er aldersgrensen 11 år. ${ }^{12}$ Hensikten med hormonbehandlingen er å undertrykke produksjonen av biologiske kjønnshormoner. Mann til kvinne-transseksuelle (MtK) får østrogenbehandling, mens kvinne til mann-transseksuelle (KtM) får testosteronbehandling. Kroppen begynner gradvis å endre seg.

Kirurgi vurderes etter ett til to år med hormonbehandling. ${ }^{13}$ Dersom personens transseksualisme er stabil og det ikke er avdekket noen særskilt risiko forbundet med inngrepene, gjennomføres de kirurgiske inngrepene. Avhengig av hvordan kroppen har utviklet seg under hormonbehandlingen, vurderes hvilken kirurgi personen har behov for. Likevel er deler av kirurgien obligatorisk. Det kan være aktuelt med mastektomi (fjerning av bryster) for KtM, eller konstruksjon av bryster for MtK. Vel et halvt til ett år etter dette vurderes genitalkirurgi. For MtK fjernes testiklene (orkiektomi) og svamplegemene, som medfører at opprinnelig reproduktiv evne opphører. Deretter konstrueres en neovagina og en neoklitoris. For KtM fjernes livmor (hysterektomi), eggledere og eggstokker (salpingo-

\footnotetext{
${ }^{8}$ Helsedirektoratet (2014).

${ }^{9}$ Diagnosekriteriet fungerer på tilsvarende måte i de fleste andre europeiske land. Trans Rights Europe Map, 2014.

${ }^{10}$ Tønseth (2010).

${ }^{11}$ OUS, Transseksual kirurgi.

${ }^{12}$ Hansen, Harry Benjamin Ressurssenter (2012), s. 8.

${ }^{13}$ OUS, Transseksual kirurgi.
} 
ooforektomi), og penis konstrueres dersom det ønskes. ${ }^{14}$ Inngrepene fører til varig infertilitet for både KtM og MtK og er et krav for å få endret fødselsnummeret.

Kirurgien utføres etter at personen har fylt 18 år. Gjennomsnittsalderen for de kirurgiske inngrepene er 21-22 år. ${ }^{15}$ Samlet sett kan utredning og behandling ta opp mot ti år. ${ }^{16}$ Årsrapporten til Nasjonal behandlingstjeneste for transseksualisme for 2013 viser 320 aktive pasienter. Av disse er det 62 barn under 18 år. ${ }^{17}$

Etter fullført kjønnsbekreftende behandling bekrefter Seksjon for transseksualisme overfor Skattedirektoratet at personen har gjennomgått kjønnsbekreftende behandling. Skattedirektoratet endrer deretter fødselsnummeret. ${ }^{18}$

I den britiske Trans Mental Health Study fra 2012 oppga 63 prosent av respondentene at de før den kjønnsbekreftende behandlingen i større grad hadde vurdert eller forsøkt å ta sitt eget liv enn etter behandlingen. Andelen som opplevde det motsatte - at de i større grad hadde vurdert eller forsøkt å ta sitt eget liv etter behandlingen - var på tre prosent. ${ }^{19}$ I samme undersøkelse sa 74 prosent av respondentene at de opplevde en bedre psykisk helse etter kjønnsbekreftende behandling, mens fem prosent meldte om dårligere psykisk helse. ${ }^{20}$ The World Professional Association for Transgender Health (WPATH) viser i syvende utgave av Standards of Care til at 97 prosent av KtM og 87 prosent av MtK opplever en bedre psykisk helse etter kjønnsbekreftende behandling. ${ }^{21}$ Det samme oppga respondentene i undersøkelsen Kjønnsbekreftende behandling gjennomført i forbindelse med forfatterens masteravhandling i 2012. Av 45 respondenter besvarte 36 personer spørsmålet om hvilken betydning kjønnsbekreftende behandling har for dem. Én informant fortalte at "[a]lternativet hadde vært å ikke leve lenger", mens en annen sa at behandlingen har

«[s]tor betydning. Jeg ser det som min måte å klare å leve resten av livet mitt noenlunde bra. Jeg har slitt med alt hele livet og hatt vanskelig for å klare/makte venner, sosialt liv, skole/studier, jobb osv. Da jeg besluttet meg for å søke behandling, var det som om jeg ikke klarte ting lenger. Jeg har i 40 år prøvd om ikke jeg bare kunne leve som jeg var, med det viste seg å ikke gå for min del. Så det handler om å

\footnotetext{
14 Tønseth (2010).

${ }^{15}$ Hansen, Harry Benjamin Ressurssenter, Behandling av kjønnsskiftepasienter.

${ }^{16}$ Helsedirektoratet 1.oktober 2012, ref. 10/5482.

${ }^{17}$ Nasjonal behandlingstjeneste for transseksualisme (2013).

${ }^{18}$ Helsedirektoratet (2014).

${ }^{19}$ Trans Mental Health Study (2012), s. 59.

${ }^{20}$ Trans Mental Health Study (2012), s. 50.

${ }^{21}$ WPATH (2011), s. 108.
} 
kunne klare å leve et noenlunde liv resten av livet mitt. Jeg ser på det som smertebehandling. Noen biologisk mann blir jeg aldri, men smerten er på mange områder i livet mitt blitt mindre og til [sic.] lettere å bære nå.»

Av respondentene fortalte 35 personer at behandlingen var livsviktig eller liknende.

Dagens behandlingstilbud har samtidig en stor bakside. Hvert år henvender om lag 120 personer seg til Seksjon for transseksualisme. Av disse får rundt 30 personer diagnosen transseksualisme og dermed adgang til kjønnsbekreftende behandling. ${ }^{22}$ Igjen står rundt 90 personer uten adekvat behandlingstilbud og uten mulighet til å endre juridisk kjønn. De som ikke får diagnosen transseksualisme, henvises tilbake til fastlegen eller spesialisthelsetjenesten. ${ }^{23}$ En annen problematisk side ved dagens behandlingstilbud viser seg i tillegg ved at behandlingstilbudet ikke er tilpasset den enkeltes behov. Dersom man har behov for å endre juridisk kjønn, må hele den kjønnsbekreftende behandlingen gjennomføres - uavhengig av om man har behov for alle de ulike delene av behandlingen eller ikke.

\subsection{Psykisk helse og behovet for å endre fødselsnummeret}

Undersøkelser angående transpersoners behov for å endre registrert kjønn skiller ikke nødvendigvis mellom personer som har og personer som ikke har diagnosen transseksualisme. Behovet for å endre registrert kjønn kan være til stede uavhengig av hvorvidt man er transseksuell.

Funksjonen som registrert kjønn og kjønn generelt har i samfunnet i dag, kan være med på å forsterke behovet for samsvar mellom registrert kjønn og kjønnsidentitet. Forventninger om hvordan man skal se ut og oppføre seg basert på kjønnsstereotype oppfatninger, kan skape vesentlig ubehag. Den britiske undersøkelsen Trans Mental Health Study fra 2012 viser en svært bekymringsverdig dårlig psykisk helse blant personer som er trans. Dårlig psykisk helse kan finne sin hele eller delvise årsak i det å være trans. I undersøkelsen hadde 29 prosent av de 633 respondentene i løpet av den siste uken forsøkt å passere som ikke-trans for å bli akseptert. Det siste året hadde 38 prosent opplevd å bli gjort narr av eller å ha blitt kalt ting fordi de var trans, og 45 prosent hadde hørt at personer som er trans, er unormale. ${ }^{24}$

\footnotetext{
${ }^{22}$ Helsedirektoratet 1.oktober 2012, ref. 10/5482, s. 3.

${ }^{23}$ van der Ros (2013), s. 65.

${ }^{24}$ Trans Mental Health Study (2012), s. 42.
} 
Forskningsrapporten Seksuell orientering og levekår baserer seg på resultater fra en spørreundersøkelse gjennomført i Norge i juni 2013. I alt deltok 1254 personer i undersøkelsen (611 menn og 643 kvinner), som blant annet dreier seg om holdninger til personer som er trans. Undersøkelsen viste en større andel negative holdninger til transpersoner og personer som har gjennomgått kjønnsbekreftende medisinsk behandling, blant menn enn blant kvinner. Mens andelen menn med negative holdninger til transpersoner var 20 prosent og 15,7 prosent til personer som har gjennomgått kjønnsbekreftende behandling, var andelen henholdsvis 9,3 prosent og 6,6 prosent blant kvinner. ${ }^{25}$ Samtidig oppga en stor andel av respondentene at de aldri har hatt kontakt med transpersoner (menn: 61,7 prosent; kvinner: 62,7 prosent) eller personer som har gjennomgått kjønnsbekreftende behandling (menn: 67,7 prosent; kvinner: 71,3 prosent). ${ }^{26}$ Undersøkelsen viste også at 24,7 prosent av menn er enige i utsagnet "Jeg synes transpersoner er frastøtende". Blant kvinnene var andelen 11,6 prosent. $^{27}$ Som påpekt av forskningsteamet, ledet av Norman Anderssen,

«angår holdningene lhbt-personer [lesbiske, homofile, bifile og transpersoner] direkte. Selvoppfattelse og handlingsrom for lhbt-personer påvirkes av befolkningens holdninger til dem. [...] [H]oldninger til lhbt-personer [har] en regulerende kraft på kjønn og seksualitet ved at de inngår i et bredere sett av normer og forestillinger om sanselighet, kvinnelighet, mannlighet, seksualitet og identitet.» ${ }^{28}$

Kjønnsbekreftende behandling skal bedre den enkeltes helse. Den svenske undersøkelsen Hälsa på lika villkor fra 2006 viste at 50 prosent av alle transpersoner i Sverige hadde vurdert å ta sitt eget liv, mens 21 prosent hadde forsøkt. Undersøkelsen viste i tillegg at selvmordstankene var sterkest i aldersgruppen 16-29 år. ${ }^{29}$

Undersøkelsen Kjønnsbekreftende behandling fra 2012 indikerer hvilken betydning det kan ha å endre juridisk kjønn. ${ }^{30}$ Av i alt 45 respondenter besvarte 37 personer dette spørsmålet. Av disse oppga 32 personer at endringen var svært viktig for dem. Én av respondentene utdypet følgende:

\footnotetext{
${ }^{25}$ Anderssen og Malterud (2013), se tabell 1 og 2 s. 130-131.

${ }^{26}$ Anderssen og Malterud (2013), se tabell 3 og 4 s. 132.

${ }^{27}$ Anderssen og Malterud (2013), se tabell 5 og 6 s. 133-134.

${ }^{28}$ Anderssen og Malterud (2013), s. 122.

${ }^{29}$ Roth (2006), s. 35-37.

${ }^{30}$ Undersøkelse gjennomført i forbindelse med masteravhandlingen Retten til kjønnsidentitet som menneskerettighet: Kan norsk forvaltningspraksis' krav om irreversibel sterilisering ved endring av fødselsnummer forsvares? (2013).
} 
«[Det har] stor betydning da reise vil bli lettere, samt at man ikke har frykt for å bli «outet» hver gang man viser bankkortet, dette skjer hver gang jeg er på apoteket og stemningen blir klein. Samt personlig selvfølelse i det at staten aksepterer at jeg er kvinne.»

En annen fortalte at

«Jeg har nå mulighet til å kunne legitimere meg som den personen jeg er [...] og slipper å måtte forklare, bli frustrert over nærgående spørsmål fra medmennesker om hvem og hva jeg er, og kan kreve å bli omtalt med rett pronomen. Jeg er en «hun» - og det føles veldig riktig og godt. [...]» ${ }^{31}$

Andre respondenter trakk på liknende måte frem betydningen det har eller vil få for hverdagen deres og hvilken belastning det er å måtte forsvare hvilket kjønn man er. Manglende endring av fødselsnummeret kan føre til at effekten av kjønnsbekreftende behandling uteblir.

\section{Lovgivning og praksis}

Innen legevitenskapen bestemmes kjønn med utgangspunkt i kromosomer, gonader og genitalia. Disse regnes som de biologiske kjønnskriteriene. ${ }^{32}$ Som vi skal se danner disse kriteriene utgangspunktet for den rettslige forståelsen av kjønn.

\subsection{Tildeling og endring av juridisk kjønn - lovverkets dikotomi} Adgangen til å endre fødselsnummeret fremgår av folkeregistreringsforskriften § 2-2. Etter bestemmelsen kan fødselsnummer endres når kjønnsstatus eller fødselsdato endres, eller etter tillatelse fra politiet. Verken folkeregisterloven eller folkeregistreringsforskriften gir opplysninger om når kjønnsstatus regnes som endret. Kriteriene for endring av fødselsnummer fremgår verken av lov, forskrift eller forarbeidene til disse. Til tross for dette er praksisen for endring av fødselsnummer ensartet i Norge. Som vist i punkt 1.1 kreves fullstendig kjønnsbekreftende behandling med irreversibel fjerning av reproduktive organer. Praksisen ble etablert før forskrift om folkeregistrering av $1994^{33}$, nå avløst av dagens forskrift av 2007. Som nevnt ble den etablert allerede på 1970-tallet gjennom medisinsk praksis og har siden den gang ikke blitt endret.

Til sammenlikning tildeler Skatteetaten fødselsnummer til nyfødte når de mottar fødselsmeldingen fra sykehuset. Innen seks måneder må barnets mor velge et navn til barnet. Når barnets navn er registrert, utstedes så fødselsattesten. Den inneholder blant annet barnets

\footnotetext{
${ }^{31}$ Respondenter i undersøkelsen Kjønnsbekreftende behandling, 2012.

${ }^{32}$ Diseth (2008), s. 576.

${ }^{33}$ Forskrift 4. mars 1994 nr. 161.
} 
fødselsnummer og må medbringes når barnet skal få pass for første gang. Mens barnejournalen har kategoriene gutt, pike, usikker ${ }^{34}$, har fødselsattesten kun to alternativer. ${ }^{35}$ Barnets kjønn må med andre ord fastsettes på et tidlig stadium. Kjønnsfastsettelsen tar utgangspunkt i de biologiske kjønnskriteriene.

Slik blir de biologiske kjønnskriteriene avgjørende både ved endring av juridisk kjønn og for fastsettelse av kjønn ved fødsel. Ved fødsel fungerer deres tilstedeværelse bestemmende, mens fraværet av disse kreves for endring av juridisk kjønn.

Folkeregistreringens inndeling av norske statsborgere i kategoriene mann og kvinne fungerer som et fundament for oppbyggingen av lovverket. Samtidig defineres ikke kategoriene mann og kvinne her. I en rettslig kontekst fremstår dermed kategoriene som gitte og uomtvistelige, mens mangfoldet i forståelse og opplevelse av kjønn synliggjøres i samfunnet for øvrig.

Selv om kategoriene ikke er underlagt noen rettslig definisjon, knyttes de til fødselsnummer og registrert kjønn, og på grunn av kriteriene for kjønnskategoriene til en medisinsk forståelse av kjønn. Kjønnskategoriene lovverket opererer med får slik sitt innhold fra den medisinske forståelsen av kjønn og blir bestemt av den. Dette kan betraktes slik at lovverkets manglende klare definisjon av kjønnskategoriene har muliggjort legevitenskapens sentrale rolle i lovverket. $^{36}$

\subsection{Steriliseringsloven}

Hvorvidt steriliseringsloven ${ }^{37}$ stenger for vilkåret om irreversibel sterilisering har vært en del av diskusjonen rundt vilkåret. Ifølge Helsedirektoratet kommer ikke steriliseringsloven til anvendelse fordi varig sterilitet i seg selv ikke er formålet bak behandlingen. ${ }^{38}$ Varig sterilitet er riktignok ikke behandlingens hovedformål, men det er likevel en vesentlig og obligatorisk del av behandlingen - og avgjørende for om behandlingen kan regnes som fullført. Til sammenlikning mente lovgiver i Sverige at det var nødvendig å lovfeste vilkåret om

\footnotetext{
${ }^{34}$ Anslagsvis fødes omtrent 300 barn hvert år med ulik grad av atypiske genitalier. I 2013 ble 14 personer henvist til den flerregionale behandlingstjenesten for usikker somatisk kjønnsutvikling ved Oslo universitetssykehus. For Haukeland universitetssykehus var antall nyhenviste 20 for 2013. Totalt er omtrent 100 personer tilknyttet den flerregionale behandlingstjenesten. Uavklart kjønn regnes som øyeblikkelig hjelp. I de fleste tilfeller gjennomføres såkalt "normaliserende" kirurgi når barnet er 3-6 måneder gammelt. Diseth (2008); Flerregional behandlingstjeneste for usikker somatisk kjønnsutvikling, Helse Sør-Øst (2013); Flerregional behandlingstjeneste for usikker somatisk kjønnsutvikling, Helse Vest (2013), s. 72-74; Bjerknes (2009).

${ }^{35}$ Forskrift 9. desember 1999 nr. 1263, § 9; Skatteetaten, Fra fødselsmelding til navnevalg.

${ }^{36}$ Kolbe (2009), s. 150.

${ }^{37}$ Lov 3. juni 1977 nr. 57.

${ }^{38}$ Helsedirektoratet 1.oktober 2012, ref. 10/5482, s. 16-17.
} 
infertilitet for at vilkåret eller inngrepet skulle gå klar av svensk steriliserings- og kastreringslovgivning. ${ }^{39}$ Resultatet ble könstillhörighetslagen ${ }^{40}$ fra 1972.

Det medisinske fakultetet i Oslo uttalte seg imot lovutkastet til den norske steriliseringsloven fra 1977. Fakultetet kritiserte at utkastet kun regulerte kastrering som ledd i kriminalitetsforebyggende arbeid, og at kastrering ved transseksualisme ikke var omtalt. Fakultetet fremhevet at det daværende steriliseringsrådet hadde behandlet saker om kastrering ved transseksualisme. De understreket både behovet for lovregulering av inngrepene og for at også slike tilfeller ble underkastet en søknadsprosedyre. Fakultetet trakk frem at det var stor uenighet både om indikasjonene for inngrepene og resultatene av inngrepene. Av den grunn mente de det var behov for at slike søknader ble behandlet av andre enn den behandlende legen. ${ }^{41}$

Steriliseringsloven «gjelder for operasjon eller inngrep som tar sikte på å oppheve en persons forplantningsevne (sterilisering) eller kjønnsdrift (kastrering)», jf. § 1. Loven gjelder ikke dersom inngrepet eller behandlingen av medisinske eller andre grunner er rettmessige etter regler utenfor loven, jf. § 1. Aldersgrensen for steriliseringsinngrep etter egen begjæring er 25 år, jf. § 2. Det kan stilles spørsmål ved om ikke aldersgrensen også bør stenge for irreversibel sterilisering av personer under 25 år når det gjøres som et ledd i å oppnå rettslig anerkjennelse av kjønnsidentiteten. Inngrepet loven regulerer, er et mindre omfattende inngrep enn ved kjønnsbekreftende behandling. Ved kjønnsbekreftende behandling fjernes de reproduktive organene, noe som etter loven regnes som kastrering, og som tidligere ble brukt kriminalitetsforebyggende. ${ }^{42}$ Ved steriliseringsinngrep etter loven lukkes egglederne eller sædlederne. Aldersgrensen ble satt til 25 år fordi man fryktet at unge mennesker som steriliserte seg i ung alder, senere skulle angre seg. Det fremstår derfor som ulogisk å oppstille fjerning av reproduktive organer som et vilkår. Det er særlig problematisk tatt i betraktning at gjennomsnittsalderen for de operative inngrepene er $21-22$ år. ${ }^{43}$

Det er påfallende hvordan lovgiver på den ene siden ønsker å verne unge mennesker, men på den andre siden ikke hindrer at unge mennesker føler seg presset til å gjennomgå en mer

\footnotetext{
${ }^{39}$ Prop. 1972: 6, pkt. 2.

${ }^{40}$ Lagen 1972: 119 om fastställande av könstillhörighet i vissa fall.

${ }^{41}$ Ot.prp. nr. 16 (1976-77), s. 10.

${ }^{42}$ Ot.prp. nr. 16 (1976-77), s. 11.

${ }^{43}$ Hansen, Harry Benjamin Ressurssenter, Behandling av kjønnsskiftepasienter.
} 
alvorlig og irreversibel operasjon ved kjønnsbekreftende behandling for å oppnå rettslig anerkjennelse av kjønnsidentiteten. Aldersgrensen i steriliseringsloven bør i det minste føre til at det stilles særlige krav til informasjonen som gis til personer under 25 år, og til forsikring om at personen virkelig ønsker å fjerne de reproduktive organene.

\subsection{Informasjon om inngrepet}

Kjønnsbekreftende behandling regnes som nødvendig helsehjelp etter pasientrettighetsloven ${ }^{44}$ § 2-1b annet ledd. ${ }^{45}$ Helsehjelp ytes på bakgrunn av informert samtykke. Kravet om samtykke etter pasientrettighetsloven skal ivareta integritetsvernet og selvbestemmelsesretten. Den enkeltes selvbestemmelsesrett er ivaretatt i tilfeller hvor en pasient på bakgrunn av tilstrekkelig informasjon frivillig samtykker i inngrepet. Det stilles krav både til informasjonen som gis, under hvilke forhold informasjonen formidles og samtykket avgis. Hvor mye som kreves - både av informasjonen og av samtykket - avhenger av inngrepets alvorlighet. Dette fremgår av pasientrettighetsloven § 4-1, jf. § 3-2. ${ }^{46}$

I dag foreligger det ingen fast praksis for å innhente samtykke forut for de kirurgiske inngrepene i forbindelse med kjønnsbekreftende behandling i Norge. ${ }^{47}$ Det er i tillegg ingen etablert ordning for hvilken informasjon pasientene får om inngrepene. ${ }^{48}$ Rikshospitalet har opplyst følgende om hvilken informasjon som gis:

\footnotetext{
«På plastikkirurgen gir vi nok mest info omkring den kirurgiske prosedyren, ev. komplikasjonsmuligheter og forventet resultat i forhold til endret kropp. Vi tar ikke stilling til hormonendringene og forsker heller ikke på dette emne. Vi har heller ingen standarisert [sic.] informasjonsbrosjyre - hver pas. får en lang, muntlig, individuell info og så forsøker vi å svare på spørsmålene pas. måtte ha. Det dreier seg imidlertid også mest om funksjonelle detaljer etter operasjonen og har som regel ikke noe med selve steriliseringen å gjøre.» ${ }^{49}$
}

Undersøkelsen Kjønnsbekreftende behandling viste at ni av $36^{50}$ respondenter hadde fått muntlig informasjon om den operative steriliseringen. Videre hadde fem personer fått både skriftlig og muntlig informasjon. I alt 20 personer hadde ikke fått informasjon om inngrepet, mens to personer ikke husket hvilken informasjon de hadde fått. To av respondentene fortalte

\footnotetext{
${ }^{44}$ Lov 2. juli $1999 \mathrm{nr} .63$.

${ }^{45}$ Warberg (2011), s. 71.

${ }^{46}$ Syse (2009), s. 325, 305.

${ }^{47}$ Sørlie (2013), kap. 5.2.2.

${ }^{48}$ OUS publiserte en nettside med informasjon om behandlingen 29.10.2013. OUS, Transseksual kirurgi.

${ }^{49}$ Bjark (2012).

${ }^{50} 14$ av respondentene var ferdig med kjønnsbekreftende behandling. 1 skulle fjerne reproduktive organer, 2 var kommet til brystkirurgien, mens 11 hadde begynt på hormoner. 10 var under utredning.
} 
at de hadde fått inngående informasjon, og at kirurgen hadde tegnet og forklart. Seks av respondentene var hovedsakelig blitt fortalt at det var en del av behandlingen eller nødvendig for å endre fødselsnummeret.

Kravet til informasjon reduseres ikke av at inngrepet fungerer som et vilkår. Inngrepets alvorlighet gjør derimot at det stilles særlige krav til helsearbeiderne om hvordan og hvilken informasjon som formidles, samt til at helsearbeiderne forsikrer seg om at pasienten har forstått informasjonen, jf. pasientrettighetsloven § 3-5 annet ledd. ${ }^{51}$ Dette er avgjørende for at hver enkelt pasient skal kunne treffe en veloverveid beslutning om hvorvidt inngrepet skal gjennomføres.

Irreversibel sterilisering er et vilkår for rettslig anerkjennelse av kjønnsidentiteten - det er både en rettighet og en fordel for den enkelte. Det gjør at det blir vanskelig å anse en eventuell samtykkeavgivelse som frivillig og gyldig etter pasientrettighetsloven. Det gjelder uavhengig av om tilstrekkelig informasjon er blitt gitt. Unntak er i de situasjoner hvor fjerning av reproduktive organer er et ønske hos den enkelte, og hvor kirurgien er nødvendig for at personen skal kunne leve i overensstemmelse med egen kjønnsidentitet.

\section{3. Økt fokus på transpersoners situasjon i Norge}

Helsedirektoratet har på oppdrag av Helse- og omsorgsdepartementet nedsatt en tverrfaglig ekspertgruppe som blant annet har som mandat å vurdere vilkåret om irreversibel sterilisering for endring av fødselsnummer. Ekspertgruppa skal også utrede hvilke kriterier som bør stilles for å endre registrert kjønn i Norge. De startet opp sitt arbeid i januar 2014 og skal komme med sine anbefalinger innen 31. januar $2015 .^{52}$

Amnesty International lanserte i februar 2014 rapporten The state decides who I am: Lack of legal gender recognition for transgender people in Europe. I rapporten vurderes transpersoners situasjon i syv land, deriblant Norge. ${ }^{53}$ Helse- og omsorgsminister Bent Høie (H) har siden uttalt at dagens praksis ikke er akseptabel, men at arbeidet med å endre den ikke vil starte opp før anbefalingene fra Helsedirektoratets ekspertgruppe foreligger i $2015 .{ }^{54}$

\footnotetext{
${ }^{51}$ Warberg (2011), s. 188; Syse (2009), s. 280.

${ }^{52}$ Helse- og omsorgsdepartementet, 13.september 2013, ref. 12/3009; Helsedirektoratet, Rettigheter for transpersoner og kjønnskorreksjonspasienter.

${ }^{53}$ Amnesty International ( 2014).

${ }^{54}$ Konstad (2014).
} 
Helse- og omsorgsdepartementet har forutsatt at ekspertgruppen konsulterer den tverrministerielle arbeidsgruppen i Danmark, samt den svenske utredningen angående de svenske kravene for endring av personnummer. ${ }^{55}$ Arbeidsgruppen i Danmark avga i februar 2014 sin rapport med utredning av tre ulike modeller for endring av juridisk kjønn. På bakgrunn av rapporten anbefalte arbeidsgruppen den såkalte erklæringsmodellen, som også ble vedtatt som lov. Erklæringsmodellen er lik den argentinske loven om endring av juridisk kjønn ${ }^{56}$. Etter modellen kan den som opplever «at tilhøre det andet køn», skriftlig søke om å få nytt CPR-nummer av CPR-kontoret og deretter endre navn og få nytt pass. Modellen oppstiller en refleksjonsperiode på seks måneder fra søknadstidspunktet. Etter utløpet av denne perioden må søkeren bekrefte ønsket om å endre juridisk kjønn før endringen finner sted. Utover dette kreves at søkeren er fylt 18 år. ${ }^{57}$ Lovforslaget ble vedtatt 11. juni 2014 med 59 mot 52 stemmer og trådte i kraft 1 . september $2014 .^{58}$

Den svenske loven om fastsettelse av kjønnstilhørighet går ikke like langt som den danske, men vilkåret om infertilitet eller sterilisering ble satt ut av kraft 19. desember 2012 da Kammarrätten i Stockholm slo fast at kravet var i strid med EMK artikkel 8 og artikkel 14. Vilkåret er nå avskaffet ved lovendring, som trådte i kraft 1. juli 2013. ${ }^{59}$

Skattedirektoratet har vurdert 40 ulike modeller for fødselsnummeret på oppdrag fra Finansdepartementet. ${ }^{60}$ Fire av disse ble gjenstand for samfunnsøkonomiske analyser. På bakgrunn av analysene anbefalte Skattedirektoratet 30. juni 2014 å beholde dagens fødselsnummer, men at informasjonen om kjønn fjernes. Opplysning om kjønn skal istedenfor fremgå av et eget felt i Folkeregisteret. Dagens borgere vil beholde eksisterende fødselsnummer. Merkostnadene ved å fjerne informasjonen om kjønn er estimert til 320 millioner kroner. Det anbefales likevel for at fødselsnummeret skal kunne tåle mulige endringer i fremtiden. Direktoratet trekker i denne sammenheng frem at dagens tokjønnsmodell blir utfordret både nasjonalt og internasjonalt - og at det er mulig at flere kjønnskategorier blir innført også i Norge i fremtiden. De andre alternativene

\footnotetext{
${ }^{55}$ Helse- og omsorgsdepartementet, 13. september 2013, ref. 12/3009.

${ }^{56}$ Lov nr. 26.743. Engelsk oversettelse tilgjengelig her: http://tgeu.org/Argentina_Gender_Identity_Law

${ }^{57}$ Justitsministeriet, dok. 585555 (2014).

${ }^{58}$ Folketinget, 11.juni 2014.

${ }^{59}$ Ds 2012:46, s. 78.

${ }^{60}$ Direktoratet fikk som tilleggsoppgave å vurdere økonomisk-administrative konsekvenser og ikke-prissatt effekt av et kjønnsløst fødselsnummer. Skatteetaten (2014), s. 13.
} 
Skattedirektoratet har vurdert, anslås å være vesentlig mer kostbare. Direktoratet foreslår at endringen trer i kraft ti år etter at Stortinget har besluttet hvilken løsning som skal velges. ${ }^{61}$

\section{Forholdet til EMK artikkel 8}

Selv om mye tyder på at dagens praksis vil bli endret, er det likevel grunn til å fremheve vilkårets problematiske forhold til EMK. Kirurgiske inngrep og hormonbehandling har fungert som betingelse for endring av juridisk kjønn siden praksisen ble etablert på 1970tallet. I forarbeidene til den svenske könstillhörighetslagen fra 1972 vurderes det tidligere vilkåret om sterilitet eller infertilitet etter § 1 som nødvendig for å unngå at juridiske menn blir gravide, og for å hindre forvirring om slektskapsforhold. Kriteriet ble vurdert som både nødvendig og rettslig holdbart. ${ }^{62}$

Den norske praksisen ble ikke underlagt noen rettslig vurdering på tilsvarende måte. Behandlingstilbudet ble derimot vurdert av medisinske eksperter i en rapport på oppdrag fra daværende helsedirektør i 1956, men uten at behandlingsalternativene eller de rettslige utfordringene som trekkes frem i rapporten, ble underkastet videre vurdering. Rapporten avdekket likevel uenighet blant ekspertene om hvorvidt kirurgiske inngrep burde anbefales. ${ }^{63}$

Spørsmålet i dag er om vilkåret om irreversibel sterilisering er i strid med retten til selvbestemmelse og privatliv etter EMK artikkel $8^{64}$ - med andre ord om det er juridisk holdbart å kreve frasigelse av muligheten til å få biologiske barn for å få endret juridisk kjønn i Norge i dag.

\subsection{EMK artikkel 8 og retten til privatliv}

EMK artikkel 8 (1) gir den enkelte rett til respekt for sitt privatliv og familieliv. Formålet med bestemmelsen er å beskytte individet mot vilkårlige inngrep fra en stats myndigheter, men pålegger samtidig konvensjonsstatene å iverksette positive tiltak til vern av rettighetene. ${ }^{65}$ Respekt sier noe om hvilke plikter staten har etter EMK overfor samfunnets borgere, som er rettighetssubjekter etter konvensjonen.

\footnotetext{
${ }^{61}$ Skatteetaten (2014), s. 2, 24.

${ }^{62}$ Prop. 1972: 6, pkt. 5 og 2.

${ }^{63}$ Bremer og Anchersen (1956).

${ }^{64}$ EMK er gitt forrang foran annen norsk lov, jf. menneskerettsloven § 3, jf. § 2.

${ }^{65}$ Møse (2002), s. 401.
} 
Begrepet privatliv favner vidt. Praksis fra EMD viser at interesser som den personlige identitet, privatsfæren, seksuell praksis og personlig autonomi er omfattet av begrepet. ${ }^{66}$ Vernet om den fysiske og psykiske integritet står helt sentralt i artikkel 8. Individets rett til å råde over egen person, både psykisk og fysisk, utgjør selve fundamentet i bestemmelsen. ${ }^{67}$

Retten til selvbestemmelse følger ikke uttrykkelig av ordlyden i EMK artikkel 8. Retten til selvbestemmelse fungerer likevel som et grunnleggende prinsipp konvensjonsbestemmelsene skal tolkes i lys av. ${ }^{68}$ Integritetsvernet og selvbestemmelsesretten er nært knyttet sammen. Professor Bjørn Henning Østenstad plasserer integritet - forstått som den personlige sfæren under retten til selvbestemmelse og fremhever at selvbestemmelsesretten er særlig viktig når det gjelder forhold av privat eller personlig karakter. ${ }^{69}$

I integritetsvernet og selvbestemmelsesretten ligger retten til å bestemme over egen kropp og til å være annerledes. ${ }^{70}$ I dette ligger også at det oppstilles en grense for hvor inngripende vilkår myndighetene kan stille for borgernes rettigheter. Den negative siden ved retten til selvbestemmelse gir hvert enkelt individ en rett til frihet fra myndighetenes urettmessige intervensjon, det vil si frihet fra inngrep som det ikke er åpnet for i artikkel 8 (2).

Vernet etter bestemmelsen er blitt utvidet gjennom praksis i EMD. Et godt eksempel på dette er hvordan kjønnsidentitet er blitt fastsatt som vernet etter retten til privatliv. Etter at EMD i en rekke saker hadde konkludert med at det lå innenfor statenes skjønnsmargin å bestemme hvorvidt postoperative transseksuelle hadde rett til å endre registrert kjønn, slo EMD fast i saken Christine Goodwin mot Storbritannia fra 2002 at manglende rettslig anerkjennelse av kjønnsidentiteten til postoperative transseksuelle innebar et brudd på EMK artikkel 8.

Domstolen understreket transseksuelles grunnleggende behov for et juridisk kjønn i overensstemmelse med kjønnsidentiteten og uttalte at forholdet var for alvorlig til at man kunne vente på at det ble etablert en felles europeisk enighet om spørsmålet. Individets behov ble ansett å være for tungtveiende, og domstolen kunne ikke se at det i vesentlig grad ville støte sentrale samfunnsinteresser. ${ }^{71}$

\subsection{Hvorvidt det foreligger et inngrep i artikkel 8}

\footnotetext{
${ }^{66}$ Popović (2013), s. 226.

${ }^{67}$ Høstmælingen (2012), s. 222-223.

${ }^{68}$ van Kück mot Tyskland, klagenr. 35968/97, avsnitt 69.

${ }^{69}$ Østenstad (2006), s. 351.

${ }^{70}$ Opsahl (1996), s. 44.

${ }^{71}$ Christine Goodwin mot Storbritannia, klagenr. 28957/95.
} 
Slik vilkåret om irreversibel sterilisering virker, innskrenker det muligheten til å oppnå rettslig anerkjennelse og endring av registrert kjønn. Personer som av ulike grunner ikke oppfyller kriteriet, har ingen mulighet til å endre juridisk kjønn og får dermed sin rett til kjønnsidentitet begrenset.

Vilkåret kan også betraktes i lys av den enkeltes negative selvbestemmelsesrett. Spørsmålet er hva som skal til for at et inngrep regnes som tvangsmessig eller ufrivillig.

Grensen mellom det frivillige og ufrivillige vurderes nærmere i saken Y.F. mot Tyrkia. En kvinne var blitt utsatt for en ufrivillig gynekologisk undersøkelse mens hun satt i varetekt. EMD uttaler følgende:
«[A] person's body concerns the most intimate aspect of private life. Thus, a compulsory medical intervention, even if it is of minor importance, constitutes an interference with this right [...]. [T]he Court considers that, in the circumstances, the applicant's wife could not have been expected to resist submitting to such an examination in view of her vulnerability at the hands of the authorities who exercised complete control over her throughout her detention [...].» ${ }^{72}$

Som EMD understreker, kan det ikke stilles for strenge krav til den motstand en person viser i situasjoner hvor vedkommende er underlegen og sårbar.

Europarådets menneskerettighetskommissær har ved flere anledninger uttalt seg om vilkåret om sterilisering for transpersoner og den sårbare situasjonen man kan befinne seg i. Kommissæren legger særlig vekt på den tvangssituasjon det innebærer for transpersoner når sterilisering anvendes som et vilkår for oppnåelse av juridisk anerkjennelse, tatt i betraktning av at endringen i mange tilfeller har en livsnødvendig funksjon. Kommissæren har blant annet fremhevet at

\footnotetext{
«the legal recognition of the person's preferred gender identity is rendered impossible without these treatments, putting the transgender person in a limbo without any apparent exit. It is of great concern that transgender people appear to be the only group in Europe subject to legally prescribed, stateenforced sterilisation.» ${ }^{73}$
}

\footnotetext{
${ }^{72}$ Y.F. mot Tyrkia, klagenr. 24209/94, avsnitt 33-34.

${ }^{73}$ Europarådets menneskerettighetskommissær (2009)2, punkt 3.2.1.
} 
Både svenske og tyske domstoler har behandlet saker angående de tidligere tilsvarende vilkårene i Sverige ${ }^{74}$ og Tyskland ${ }^{75}$. Etter den svenske könstillhörighetslagen krevdes sterilisering eller mangel på forplantningsevne for å få endret personnummeret. Kravet innebar ikke fjerning av reproduktive organer. Kammarrätten i Stockholm konkluderte i desember 2012 med at vilkåret var et påtvunget kroppslig inngrep som krenket den enkeltes integritetsvern. Domstolen understreket at det ikke i seg selv vil være et tvangsmessig inngrep dersom den enkelte ikke kan forhindre inngrepet. Men dersom inngrepet fungerer som et vilkår for oppnåelse av en fordel eller en rettighet, vil det som regel bli ansett som tvangsmessig. Det tvangsmessige elementet ved inngrepet, nemlig at det var nødvendig for å få endret personnummeret, gjorde ifølge domstolen at vilkåret var i strid med EMK artikkel 8. Kammarrätten viste også til at vilkåret var diskriminerende og i strid med forbudet mot diskriminering etter EMK artikkel 14, i og med at vilkåret var rettet mot en bestemt gruppe, nemlig personer som er transseksuelle. ${ }^{76}$

Den tyske forfatningsdomstolen konkluderte på liknende vis i 2011. Domstolen kom til at vilkåret om sterilisering etter den tyske Transsexuellengesetz § 8 var i strid med den tyske grunnlovens artikkel 2 avsnitt 1 og 2 i kombinasjon med artikkel 1 første avsnitt om integritetsvern. Domstolen understreket at det dreier seg om tvang når man må gjennomgå operative inngrep som medfører tap av forplantningsevnen for å oppnå rettslig anerkjennelse av egen kjønnsidentitet. Dersom man ikke gjennomgår inngrepene, mister man muligheten for rettslig anerkjennelse av kjønnsidentiteten. Konsekvensen blir et liv i uoverensstemmelse med kjønnsidentiteten, og den enkeltes integritetsvern krenkes. Velger man derimot å gjennomgå inngrepene, med de fysiske endringene og funksjonstap de innebærer, vil man oppnå rettslig anerkjennelse av egen kjønnsidentitet. For personer som ikke ønsker inngrepene, men som likevel fjerner reproduktive organer for å oppnå rettslig anerkjennelse av kjønnsidentiteten, krenkes selvbestemmelsesretten og integritetsvernet. Den psykiske belastningen det kan innebære å leve et liv hvor juridisk kjønn og eget, selvopplevd kjønn ikke samsvarer, kan føre til at man ikke ser noen annen utvei enn å gjennomgå inngrepene. Inngrepene blir dermed ikke frivillige. ${ }^{77}$ Av den grunn kom forfatningsdomstolen til at vilkåret var i strid med den tyske grunnloven.

\footnotetext{
${ }^{74}$ Vilkåret om sterilisering var i Sverige tidligere regulert i lagen om könstillhörighet $§ 1$ annet ledd, men ble opphevet ved lovendring 1. juli 2013.

${ }^{75}$ BVerfG, 1 BVR 3295/07 av 11. januar 2011.

${ }^{76}$ Kammarrätten i Stockholm, målnr. 1968-12, avsagt 19. desember 2012.

${ }^{77}$ BVerfG, 1 BVR 3295/07 av 11. januar 2011.
} 
På samme måte griper det norske vilkåret om irreversibel sterilisering inn i retten til privatliv etter EMK artikkel 8.

\subsection{Tillatte inngrep etter EMK artikkel 8 nr. 2}

Spørsmålet er om det likevel foreligger forhold som fører til at inngrepet i artikkel 8 (1) er tillatt. Artikkel 8 (2) regulerer i hvilke tilfeller den enkeltes rett til respekt for sitt privatliv eller familieliv kan innskrenkes, eller på hvilke vilkår det er tillatt å gripe inn i denne retten. EMD har utviklet en tretrinnstilnærming for å vurdere hvorvidt et inngrep kan tolereres. Det må først, som i punkt 4.2, avgjøres om det er skjedd et inngrep i retten eller friheten etter artikkel 8. Deretter må det vurderes om inngrepet likevel kan tillates. For det første forutsetter det at inngrepet er foreskrevet ved lov. Videre må inngrepet være begrunnet $\mathrm{i}$ et av formålene som følger av artikkel 8 (2) - formålet må med andre ord være legitimt. I tillegg må inngrepet være nødvendig i et demokratisk samfunn og forholdsmessig. I

forholdsmessighetsvurderingen ligger kravene om at inngrepet må være egnet og nødvendig for å sikre det legitime formålet. Til slutt må det vurderes om inngrepet er proporsjonalt med det som søkes oppnådd. ${ }^{78}$ EMD taler gjerne om at det må foreligge den nødvendige balanse mellom samfunnets og individets interesser. ${ }^{79}$

\subsubsection{Krav om lovhjemmel}

Kravet om lovhjemmel forutsetter at inngrepet har «some basis in domestic law». ${ }^{80}$ «Law» kan være skreven lov eller uskreven rett, såfremt det har en forankring i nasjonal rett og tilfredsstiller kravet til tilgjengelighet og forutberegnelighet. EMD har lagt til grunn at lover kan overlate et visst skjønn til offentlige myndigheter, men at omfanget av skjønnet må fremgå av loven. ${ }^{81}$

Det rettslige grunnlaget for vilkåret om irreversibel sterilisering er langvarig forvaltningspraksis. Irreversibel sterilisering er en handling som ellers regnes som grov legemsbeskadigelse etter straffeloven, jf. §§ 231 og 9. På grunn av vilkårets alvorlighet forsterkes kravet til det rettslige grunnlaget. Langvarig forvaltningspraksis er alene ikke tilstrekkelig rettslig grunnlag for inngrepet. Inngrepet kan allerede av den grunn ikke tillates etter EMK artikkel 8 (2).

\subsubsection{Nødvendig i et demokratisk samfunn}

\footnotetext{
${ }^{78}$ Andenæs (2014), s. 63-64.

${ }^{79}$ Popović (2013), s. 219.

${ }^{80}$ Y.F. mot Tyrkia, klagenr. 24209/94, avsnitt 41.

81 The Sunday Times mot Storbritannia, klagenr. 6538/74, avsnitt 47 og 49.
} 
Ulike formål kan legitimere inngrep i rettighetene og frihetene etter EMK artikkel 8.

Opplistingen i bestemmelsen er uttømmende. Etter EMK artikkel 8 (2) kan

konvensjonsstatene gripe inn i disse dersom formålet er å beskytte blant annet moral eller andres rettigheter eller friheter.

I og med at moral er et fremtredende forhold når EMD behandler saker angående LHBTpersoner, konsentreres vurderingen om moral. EMD har ved flere anledninger uttrykt at det ikke er mulig å definere moral entydig. Hva som er moralsk eller umoralsk, varierer blant konvensjonsstatene. ${ }^{82}$ Spørsmål om blant annet transpersoners adgang til å endre registrert kjønn $^{83}$, abort ${ }^{84}$, assistert befruktning ${ }^{85}$ og homoseksualitet ${ }^{86}$ anses å dreie seg om moralske forhold. EMD har i slike tilfeller i varierende grad vurdert om det har vært legitimt å gripe inn i EMK artikkel 8 av hensyn til blant annet samfunnsmoralen.

I tillegg til å beskytte et legitimt formål må inngrepet være nødvendig i et demokratisk samfunn for at det skal være tillatt. Inngrepet må være egnet, nødvendig og forholdsmessig. Vilkåret om irreversibel sterilisering må, etter praksis fra EMD, oppfylle et presserende samfunnsmessig behov. ${ }^{87}$ EMD uttaler følgende i saken S.H. and Others mot Østerrike:

«Where a particularly important facet of an individual's existence or identity is at stake, the margin allowed to the State will normally be restricted [...]. Where, however, there is no consensus within the member States of the Council of Europe, either as to the relative importance of the interest at stake or as to the best means of protecting it, particularly where the case raises sensitive moral or ethical issues, the margin will be wider $[\ldots] . »{ }^{88}$

Det skal med andre ord mer til for at inngrep som angår sentrale sider ved en persons identitet, tillates. Årsaken til inngrepet må være mer alvorlig enn ellers.

Følgen av ikke å gjennomgå de kirurgiske inngrepene, er at man ikke oppnår rettslig anerkjennelse av kjønnsidentiteten. EMD har uttalt at

\footnotetext{
${ }^{82}$ Handyside mot Storbritannia, klagenr. 5493/72, avsnitt 48.

${ }^{83}$ Christine Goodwin mot Storbritannia, klagenr. 28957/95.

${ }^{84}$ A, B og C mot Irland, klagenr. 25579/05.

${ }^{85}$ S.H. and Others mot Østerrike, klagenr. 57813/00.

${ }^{86}$ Dudgeon mot Storbritannia, klagenr. 7525/76.

${ }^{87}$ Høstmælingen (2012), s. 123.

${ }^{88}$ S.H. and Others mot Østerrike, klagenr. 57813/00, avsnitt 94.
} 
«[t]he stress and alienation arising from a discordance between the position in society assumed by a post-operative transsexual and the status imposed by law which refuses to recognise the change of gender cannot, in the Court's view, be regarded as a minor inconvenience arising from a formality. A conflict between social reality and law arises which places the transsexual in an anomalous position, in which he or she may experience feelings of vulnerability, humiliation and anxiety.» ${ }^{89}$

Konsekvensene av ikke å oppnå rettslig anerkjennelse av kjønnsidentiteten kan være alvorlige. ${ }^{90}$ Velger man derimot å gjennomgå de kirurgiske inngrepene, vil det, i tillegg til å dreie seg om alvorlige inngrep, medføre varig tap av biologisk, reproduktiv evne. På motsatt side står samfunnets interesse i å videreføre vilkåret for å beskytte moralen og for å oppstille to klart distinkte kjønnskategorier. Veies individets interesser mot samfunnets interesser blir det vanskelig å argumentere for at behovet for å beskytte moralen bør gis forrang. Synet på utfordring av kjønnskategoriene som noe umoralsk bør gis vesentlig mindre vekt.

EMD poengterer følgende i saken Christine Goodwin fra 2002:

«[S]ociety may reasonably be expected to tolerate a certain inconvenience to enable individuals to live in dignity and worth in accordance with the sexual identity chosen by them at great personal cost.» ${ }^{91}$

En videreføring av vilkåret vil hindre at samfunnsutviklingen og endringen av samfunnsmoralen går sin dynamiske vei til stadig større åpenhet for samfunnets mangfold. ${ }^{92}$ Individets behov for selvbestemmelse over egen kropp og egen reproduktiv evne bør her veie vesentlig tyngre enn de ulemper og vansker deler av befolkningen kan ha med å akseptere at dagens kjønnskategorier blir mer åpne og rommer et større mangfold enn det dagens forvaltningspraksis åpner for.

Følgene av å oppheve vilkåret fremstår ikke som uoverkommelige. Skattedirektoratet har allerede i sine anbefalinger for nytt fødselsnummersystem tatt høyde for en fremtid med flere enn to kjønnskategorier og dermed for et større synlig mangfold. En endring av praksis fremstår heller ikke på andre områder som for krevende. Fra endringen i Danmark kan vi blant annet se at utfordringer knyttet til kjønnsspesifikke betegnelser i lovverket kan løses

\footnotetext{
${ }^{89}$ Christine Goodwin mot Storbritannia, klagenr. 28957/95, avsnitt 77.

${ }^{90}$ Se punkt 1.2.

${ }^{91}$ Christine Goodwin mot Storbritannia, klagenr. 28957/95, avsnitt 91.

92 Se punkt 1.2.
} 
gjennom mindre lovendringer. I sundhedsloven erstattes eksempelvis «kvinder ved graviditet» med «gravide». ${ }^{93}$

I dag kreves sterilisering, enten kirurgisk fjerning av reproduktive organer, sterilisering i vanlig forstand eller infertilitet i 22 av 37 europeiske land som har en ordning for endring av juridisk kjønn. ${ }^{94}$ Med endringene i Sverige, Danmark og Nederland de siste årene går utviklingen i Nord- og Vest-Europa i retning av endring av juridisk kjønn uten krav om infertilitet og kirurgiske inngrep.

Tatt i betraktning de alvorlige konsekvensene vilkåret om irreversibel sterilisering har for personer som ikke ønsker inngrepet, er begrunnelsen for vilkåret ikke tilstrekkelig for å legitimere det etter EMK artikkel 8 (2). I tillegg mangler det tilstrekkelig rettslig grunnlag. Vilkåret om irreversibel sterilisering innebærer dermed et brudd på EMK artikkel 8 og retten til privatliv.

\section{Avslutning}

Motstanden mot mer åpne kjønnskategorier følger 70-tallets begrunnelse for vilkåret. Det kan oppfattes slik at det å blande biologiske kvinners og menns ulike reproduktive roller, og slik forstyrre det binære tokjønnssystemet, vil ramme samfunnet på en problematisk måte som vil skape et uovervinnelig kaos. Utelatt fra diskursen blir da at selv dette systemet er konstruert det har ikke oppstått som følge av en nødvendighet, men heller som en av flere mulige måter å konstruere samfunnet og samfunnets kjønn på. I dagens moderne samfunn med fokus på menneskerettigheter bør det være tid for å forstå kjønn på nettopp en menneskerettighetskonform måte.

\section{Litteraturliste:}

Amnesty International. The state decides who I am: Lack of legal gender recognition for transgender people in Europe. 2014.

http://www.amnesty.org/en/library/asset/EUR01/001/2014/en/13af83a1-85f5-476f-9fe9b931f2b2a9f3/eur010012014en.pdf

\footnotetext{
${ }^{93}$ Lov nr. 744 af 25. juni 2014.

94 Trans Rights Europe Map, 2014; Lov nr. 752 af 25. juni 2014 [Danmark].
} 
Anchersen, Per og Langfeldt, Gabriel (utvalgets flertall). Upublisert utredning til Helsedirektøren.

Oslo, 1956.

Andenæs, Mads. Menneskerettene. I: Knophs oversikt over Norges rett. 14. utg. Oslo, 2014, s. $61-71$.

Anderssen, Norman og Kirsti Malterud. Seksuell orientering og levekår. Bergen, 2013.

Bjark, Therese Halvorsen. E-post. 2. august 2012.

Bjerknes, Robert. Feil i somatisk kjønnsutvikling. I: Generell veileder i pediatri. Norsk Barnelegeforening, rev. 2009.

Bremer, Johan (utvalgets mindretall). Upublisert utredning til Helsedirektøren. Oslo, 1956.

Brev 01.10.2012, ref. 10/5482, fra Helsedirektoratet til Helse- og omsorgsdepartementet.

Brev 13.09.2013, ref. 12/3009, fra Helse- og omsorgsdepartementet til Helsedirektoratet.

BVerfG, 1 BvR 3295/07 av 11. januar 2011.

http://www.bundesverfassungsgericht.de/entscheidungen/rs20110111_1bvr329507.html

Diseth, Trond H.. Barn født med uklare kjønnskarakteristika. I: Tidsskrift for Den norske legeforening. Årg. 5 (2008), s. 576-580.

Ds 2012:46. Avskaffande av steriliseringskrav som villkor för ändrad könstillhörighet.

Europarådets menneskerettighetskommisær. Human Rights and Gender Identity. CommDH/IssuePaper(2009)2. Strasbourg, 2009.

Flerregional behandlingstjeneste for usikker somatisk kjønnsutvikling, Helse Sør-Øst. Årsrapport 2013: Flerregional behandlingstjeneste for usikker somatisk kjønnsutvikling. 
http://forskningsprosjekter.ihelse.net/visningsenterrapport.aspx?reportId=1318 [sitert 16.07.2014].

Folketinget. L 182 Forslag til lov om ændring af lov om Det Centrale Personregister. http://www.ft.dk/samling/20131/lovforslag/L182/index.htm [sitert 28. juli 2014].

Forskrift om delegering av myndighet til Skattedirektoratet etter lov om folkeregistrering $\S 3$, § 4 og § 15 av 2. mars 2007 nr. 1263.

Forskrift om folkeregistrering av 4. mars 1994 nr. 161.

Forskrift om folkeregistrering av 9. november 2007 nr. 1268.

Forskrift om pass av 9. desember 1999 nr. 1263.

Hansen, Tone Maria (Harry Benjamin Ressurssenter). Behandling av kjønnsskiftepasienter på Rikshospitalet.

http://www.hbrs.no/filestore/BehandlingavkjnnsskiftepasienterpRikshospitalet.pdf

Hansen, Tone Maria (Harry Benjamin Ressurssenter). Håndbok: Kjønnskorrigerende behandling Rikshospitalet. Oslo, 2012.

Helsedirektoratet. Endring av juridisk kjønn. 2014. http://helsedirektoratet.no/helse-ogomsorgstjenester/endring-av-juridisk-kjonn/Sider/default.aspx [sitert 11. mars 2014].

Helsedirektoratet. ICD-10 Den internasjonale statistiske klassifikasjonen av sykdom og beslektede helseproblemer. 2014.

http://finnkode.helsedirektoratet.no/\#|icd10|ICD10SysDel|2613619|flow [sitert 11. mars 2014].

Helsedirektoratet. Rettigheter for transpersoner og kjønnskorreksjonspasienter. 2014. http://helsedirektoratet.no/Om/nyheter/Sider/rettigheter-for-transpersoner-ogkjonnskorreksjonspasienter-.aspx [sitert 18. juli 2014]. 
Helse Vest RHF. Faglig rapportering 2013: Forskningsprosjekter, nasjonale og regionale funksjoner, s. 72-74.

Høstmælingen, Njål. Internasjonale menneskerettigheter. 2. utg. Oslo, 2012.

Justitsministeriet. Rapport fra arbejdsgruppen om juridisk kønsskifte. Dok. 585555. Saksnr. 2012-270-0021/27. Februar 2014.

Kammarrätten i Stockholm, målnr. 1968-12, avsagt 19. desember 2012.

Kolbe, Angela. Intersex, a Blank Space in German Law? I: Critical Intersex. Morgan Holmes (red.). England, 2009, s. 147-171.

Konstad, Margrete. Helseministeren lover å gjøre det lettere for transpersoner å endre kjønn «på papiret». NRK. 26. juni 2014.

Könstillhörighetslagen. Lagen 1972: 119 om fastställande av könstillhörighet i vissa fall.

LOV nr. 752 af 25. juni 2014 om ændring af lov om Det Centrale Personregister.

LOV nr. 744 af 25. juni 2014 om ændring af sundhedsloven og lov om assisteret reproduktion i forbindelse med behandling, diagnostik og forskning m.v.

Lov om folkeregistrering (folkeregisterloven) av 16. januar $1970 \mathrm{nr} .01$.

Lov om pasient- og brukerrettigheter (pasientrettighetsloven) av 2. juli 1999 nr. 63.

Lov om sterilisering (steriliseringsloven) av 3. juni 1977 nr. 57.

McNeil, Jay... [et al.].Trans Mental Health Study 2012. Edinburgh, 2012.

Møse, Erik. Menneskerettigheter. Oslo, 2002. 
Nasjonal behandlingstjeneste for transseksualisme, OUS. Årsrapport 2013: Nasjonal behandlingstjeneste for transseksualisme.

http://forskningsprosjekter.ihelse.net/visningsenterrapport.aspx?reportId=1317 [sitert 17. juli 2014].

Opsahl, Torkel. Internasjonale menneskerettigheter: En innføring. 2. utg. Oslo, 1996.

Oslo Universitetssykehus. Transseksual kirurgi. 2013. http://www.oslo-

universitetssykehus.no/pasient/behandlinger/transseksual-kirurgi [sitert 17. juli 2014].

Ot.prp. nr. 10. (1969-70) Om lov om folkeregistrering.

Ot.prp. nr. 16 (1976-77) Om lov om sterilisering mv.

Popović, Dragoljub. European human rights law - a manual: An introduction to the Strasbourg court and its jurisprudence. Haag, 2013.

Prop. 1972:6 Kungl. Maj:ts proposition med förslag till lag om fastställande av könstillhörighet i vissa fall, m.m.

Roth, Niklas, Gunnel Boström og Karin Nykvist. Hälsa på lika villkor? Hälsa och livsvillkor bland HBT-personer. Stockholm, 2006.

Skatteetaten. D-nummer.

http://www.skatteetaten.no/no/Person/Skattekort-og-forskuddsskatt/Utenlandskarbeidstaker/D-nummer/D-nummer1/ [sitert 30. juli 2014].

Skatteetaten. Fra fødselsmelding til navnevalg - steg for steg.

http://www.skatteetaten.no/no/Person/Folkeregister/Fodsel-og-navnevalg/Barn-fodt-i-

Norge/Fra-fodsel-til-navnevalg---steg-for-steg/Start/ [sitert 30. juli 2014].

Skatteetaten. Konseptvalgutredning: Ny personidentifikator i Folkeregisteret. Versjon 1.0. 30. juni 2014. 
Syse, Aslak. Pasientrettighetsloven med kommentarer. 3.utg. Oslo, 2009.

Sørlie, Anniken. Retten til kjønnsidentitet som menneskerettighet: Kan norsk forvaltningspraksis' krav om irreversibel sterilisering ved endring av fødselsnummer forsvares? Oslo, 2013. (Kvinnerettslig skriftserie; nr. 90/2013).

The World Professional Association for Transgender Health (WPATH). Standards of Care for the health of transsexual, transgender, and gender nonconforming people. 7. utg. Atlanta (GA), 2011.

Transgender Europe. Argentina Gender Identity Law.

http://tgeu.org/Argentina_Gender_Identity_Law [sitert 22. september 2014].

Trans Rights Europe Map, May 2014.

http://www.tgeu.org/sites/default/files/Trans_Map_Index_2014.pdf

Transsexuellengesetz. Gesetz über die Änderung der Vornamen und die Feststellung der Geschlechtzugehörigkeit in besonderen Fällen: Transsexuellengesetz. 1980. [Tyskland].

Tønseth, K. A. ... [et al.]. Kjønnskorrigerende kirurgi ved transseksualisme. I: Tidsskrift for Den norske legeforening. Årg. 130 (2010), s. 376-379.

van der Ros, Janneke. Alskens folk: Levekår, livssituasjon og livskvalitet for personer med kjønnsidentitetstematikk. Hamar, Likestillingssenteret, 2013.

Warberg, Lasse A. Norsk helserett. 2. utg. Oslo, 2011.

Østenstad, Bjørn Henning. Grunnverdiar og frunnomgrep i debatten om bruk av tvang mot utviklingshemma og demente. I: Nordic Journal of Human Rights. Årg. 04 (2006), s. 343361.

Avgjørelser fra Den europeiske menneskerettighetsdomstolen

Handyside mot Storbritannia. Dom av 7. desember 1976, klagenr. 5493/72. 
The Sunday Times mot Storbritannia. Dom av 26. april 1979, klagenr. 6538/74.

Dudgeon mot Storbritannia. Dom av 22. oktober 1981, klagenr. 7525/76.

Christine Goodwin mot Storbritannia. Dom av 11. juli 2002, klagenr. 28957/95.

van Kück mot Tyskland. Dom av 12. juni 2003, klagenr. 35968/97.

Y.F. mot Tyrkia. Dom av 22. juli, 2003, klagenr. 24209/94.

A, B og C mot Irland. Dom av 16. desember 2010, klagenr. 25579/05.

S.H. and Others mot Østerrike. Dom av 3. november 2011, klagenr. 57813/00. 